studies have shown that the percentage of ring sideroblasts in MDS is not prognostically important. Thus, in the revised WHO classification, a diagnosis of MDS-RS may be made even in the presence of only 5\% of ring sideroblasts in cases with SF3B1 mutation. MDS-RS cases will be subdivided into cases with single lineage dysplasia (previously classified as RARS) and cases with multilineage dysplasia (previously classified as refractory cytopenia with multilineage dysplasia). Furthermore, RARS-T has been accepted as an entity and termed MDS/ myeloproliferative neoplasm (MPN) with ring sideroblasts and thrombocytosis (MDS/MPN-RS-T) in the 2016 classification. Unlike MDS-RS, the number of ring sideroblasts required for a diagnosis of MDS/MPN-RS-T is 15\%, irrespective of the presence or absence of a SF3B1 mutation [4]. As described in the case of Narang et al., in a young female of 18 years old without a history of persistent refractory cytopenia(s), a diagnosis of MDS can only be established after exclusion of secondary causes such as nutritional deficiencies [1]. An adequate trial with hematinics (vitamin B12, folic acid, and pyridoxine) is needed in such cases. After exclusion of secondary causes, if cytopenia(s) still persists, a repeat bone marrow examination with cytogenetic and molecular studies can be considered to establish the diagnosis of a clonal hematopoietic disease such as MDS or MDS/MPN.

Keywords: Refractory anemia with ring sideroblasts, RARS with thrombocytosis, Myelodysplastic syndrome/myeloproliferative neoplasm with ring sideroblasts and thrombocytosis
Anahtar Sözcükler: Halka sideroblastlı refrakter anemi, Trombositoz ile birlikte RARS, Halka sideroblast ve trombositoz ile birlikte miyelodisplastik sendrom/miyeloproliferatif neoplazi

Conflict of Interest: The authors of this paper have no conflicts of interest, including specific financial interests, relationships, and/or affiliations relevant to the subject matter or materials included.

\section{References}

1. Narang NC, Kotru M, Rao K, Sikka M. Megaloblastic anemia with ring sideroblasts is not always myelodysplastic syndrome. Turk J Hematol 2016;33:358-359.

2. Cazzola $M$, Invernizzi R. Ring sideroblasts and sideroblastic anemias. Haematologica 2011;96:789-792.

3. Papaemmanuil E, Cazzola M, Boultwood J, Malcovati L, Vyas P, Bowen D, Pellagatti A, Wainscoat JS, Hellstrom-Lindberg E, Gambacorti-Passerini C, Godfrey AL, Rapado I, Cvejic A, Rance R, McGee C, Ellis P, Mudie $\sqcup$, Stephens PJ, McLaren S, Massie CE, Tarpey PS, Varela I, Nik-Zainal S, Davies HR, Shlien A, Jones D, Raine K, Hinton J, Butler AP, Teague JW, Baxter EJ, Score J, Galli A, Della Porta MG, Travaglino E, Groves M, Tauro S, Munshi NC, Anderson KC, El-Naggar A, Fischer A, Mustonen V, Warren AJ, Cross NC, Green AR, Futreal PA, Stratton MR, Campbell PJ; Chronic Myeloid Disorders Working Group of the International Cancer Genome Consortium. Somatic SF3B1 mutation in myelodysplasia with ring sideroblasts. N Engl J Med 2011;365:1384-1395.

4. Arber DA, Orazi A, Hasserjian R, Thiele J, Borowitz MJ, Le Beau MM, Bloomfield CD, Cazzola M, Vardiman JW. The 2016 revision to the World Health Organization classification of myeloid neoplasms and acute leukemia. Blood 2016;127:2391-2405.

\title{
Therapeutic International Normalized Ratio Monitoring
}

\section{Terapötik Uluslararası Normalleştirilmiş Oran İlemi}

\author{
Beuy Joob1, Viroj Wiwanitkit2 \\ 1Sanitation 1 Medical Academic Center, Bangkok, Thailand \\ ${ }^{2}$ Hainan Medical University, Haikou, China
}

\section{To the Editor,}

The report on "Warfarin dosing and time required to reach therapeutic international normalized ratio in patients with hypercoagulable conditions" was very interesting [1]. Kahlon et al. concluded that "Patients with hypercoagulable conditions require approximately $10 \mathrm{mg}$ of additional total warfarin dose and also require, on average, 2 extra days to reach therapeutic international normalized ratio (INR) as compared to controls."
The big concern in this report regards the technique used for INR measurement. Kahlon et al. did not mention this and might not have noted the problem of measurement of INR in the followup of the patient. The quality control of the measurement is very important and measurements from different laboratory techniques and settings can be a factor leading to error in laboratory results $[2,3]$. It is noted that the local calibration in correcting the variability in INR determination and the difference between batches has to be controlled [4]. 
Keywords: Monitoring, International normalized ratio, Hemostasis

Anahtar Sözcükler: İzlem, Uluslararası normalleştirilmiş oran, Hemostaz

Conflict of Interest: The authors of this paper have no conflicts of interest, including specific financial interests, relationships, and/or affiliations relevant to the subject matter or materials included.

\section{References}

1. Kahlon $P$, Nabi S, Arshad A, Jabbar A, Haythem A. Warfarin dosing and time required to reach therapeutic international normalized ratio in patients with hypercoagulable conditions. Turk J Hematol 2016;33:299-303.

2. Favaloro EJ, McVicker W, Lay M, Ahuja M, Zhang Y, Hamdam S, Hocker N. Harmonizing the international normalized ratio (INR): standardization of methods and use of novel strategies to reduce interlaboratory variation and bias. Am J Clin Pathol 2016;145:191-202.

3. Sølvik UØ, Petersen PH, Monsen G, Stavelin AV, Sandberg S. Discrepancies in international normalized ratio results between instruments: a model to split the variation into subcomponents. Clin Chem 2010;56:1618-1626.

4. Wongtiraporn W, Opartkiattikul N, Tientadakul P. The value of local ISI calibration in correcting the variability in INR determination. Siriraj Hosp Gaz 2003;55:381-384.

\title{
Iron Overload in Hematopoietic Stem Cell Transplantation
}

\author{
Hematopoetik Kök Hücre Transplantasyonunda Așırı Demir Yüklenmesi
}

\author{
Sora Yasri1, Viroj Wiwanitkit² \\ ${ }^{1}$ KMT Primary Care Center, Bangkok, Thailand \\ 2 Wiwanitkit House, Bangkok, Thailand
}

\section{To the Editor,}

We read the publication entitled "Current Review of Iron Overload and Related Complications in Hematopoietic Stem Cell Transplantation" with great interest [1]. As summarized by Atilla et al. [1], "Organ dysfunction due to iron overload may cause high mortality rates and therefore a sufficient iron chelation therapy is recommended". We would like to share the experience from our settings where there is a very high prevalence of thalassemia and transplantation is the only curative treatment.

Iron overload is common among transfusion-dependent thalassemia patients and transfusion during transplantation might increase the risk of the complication of iron overload. However, in clinical practice, the problem is not common and improvement of the patients after transplantation is reported. According to the recent report by Inati et al. [2], with standard chelation therapy, the outcome of thalassemic patients undergoing stem cell transplantation is usually favorable. The use of the standard dosage of deferoxamine, with or without phlebotomy, accompanied with close iron status monitoring can be effective $[2,3]$. It can be seen that stem cell transplantation can be problematic despite there being a need of hypertransfusion during the process even though the patient might have an underlying severe iron overload condition such as thalassemia.

Keywords: Iron, Overload, Hematopoietic stem cell, Transplantation

Anahtar Sözcükler: Demir, Aşırı yüklenme, Hematopoietik kök hücre, Transplantasyon

Conflict of Interest: The authors of this paper have no conflicts of interest, including specific financial interests, relationships, and/or affiliations relevant to the subject matter or materials included.

\section{References}

1. Atilla $E$, Toprak SK, Demirer T. Current review of iron overload and related complications in hematopoietic stem cell transplantation. Turk J Hematol 2016 [Epub ahead of print].

2. Inati $A$, Kahale $M$, Sbeiti $N$, Cappellini MD, Taher AT, Koussa S, Nasr TA, Musallam KM, Abbas HA, Porter JB. One-year results from a prospective randomized trial comparing phlebotomy with deferasirox for the treatment of iron overload in pediatric patients with thalassemia major following curative stem cell transplantation. Pediatr Blood Cancer 2017;64:188-196.

3. Angelucci E, Pilo F. Management of iron overload before, during, and after hematopoietic stem cell tranplantation for thalassemia major. Ann N Y Acad Sci 2016;1368:115-121. 